\title{
Bireylerin Yaşlılık Algısının Sağlık Hizmeti Kullanımına Etkisia
}

\author{
Rabia Fettahoğlub, c, Ramazan Erdem ${ }^{\mathrm{d}}$
}

\section{Özet}

Modern dünyada, Batı ülkelerinin bilim ve teknolojisindeki gelişmelerin bir sonucu olarak sosyal değişimler yaşanmış ve insan yaşamı uzamıştır. Modernleşmenin kentleşme, göç, kadınların iş yaşamındaki aktif rol alması ve çekirdek aile yapısına geçiş gibi sonuçları yaşlılık algısında değişiklikler meydana getirmiştir. Bu çalışmada bireylerin yaşlılık algısı ve sağlık hizmeti kullanımı ve bunlar arasındaki etki incelenmiştir. Araştırmada 500 kişilik bir örneklem grubuna anket uygulanmıştır. Yaşlılık algısını ölçebilmek için Eser ve diğerleri tarafından Türkçeye uyarlanan Avrupa Yaşlanma Tutum Ölçeği (AAQ) kullanılmıştır. Bireyler yaşlılığı; kayıpların olduğu bir dönem şeklinde algıladıkça daha fazla aile hekimi ve klinik hizmeti kullanmaktadır. Neticede olarak katılımcılar; yaşlılı̆g belli yetilerin kaybedildiği bir zaman olarak algıladıkça daha fazla polikinik, aile hekimi ve klinik sağlık hizmeti kullanmıştır. Bunun yanı sıra katılımcılar yaşlılığı tecrübe ve örnek olunması bir dönem olarak algıladıkça özel hekime daha az başvurmuştur.
Anahtar Kelimeler

Yaşlilık

Yaşlılık Algisı

Sağlık Hizmeti Kullanımı

Modern Zaman

Makale Hakkında

Geliş Tarihi: 23.11.2019

Kabul Tarihi: 25.12.2020

Doi: 10.18026/cbayarsos.650251

\section{The Effect of Individuals' Perception of Aging on Healthcare Use}

\begin{abstract}
As a result of the developments in the science and technology of Western countries in the modern world, social changes have occurred and human life has been prolonged. The consequences of modernization such as urbanization, migration, the active role of women in business life and the transition to the nuclear family structure have caused changes in the perception of old age. In this study, individuals' perception of aging and healthcare use and the effect between them were examined. In the study, a questionnaire was applied to a sample group of 500 people. The European Aging Attitude Scale (AAQ), adapted to Turkish by Eser and others, was used to measure the perception of aging. Individuals old age; more family physicians and clinical services are used as it is perceived as a period of losses. As a result, the participants; As he perceived old age as a time when certain abilities were lost, he used more polyclinics, family physicians and clinical health services. In addition, as the participants perceived old age as an experience and an example, they applied less to the private physician..
\end{abstract}

\begin{tabular}{r} 
Keywords \\
\hline Old Age \\
Aging Perception \\
Health Service Use \\
Modern Time \\
About Article \\
\hline Received: 23.11 .2019 \\
Accepted: 25.12 .2020
\end{tabular}

Doi: $10.18026 /$ cbayarsos.650251

\footnotetext{
a Bu çalışma Rabia Fettahoğlu'nun “Bireylerin Yaşlılık ve Ölüm Algısının Sağlık Hizmeti Kullanımına Etkisi” adlı yüksek lisans tezinden türetilmiştir. Bu çalışma 20-23 Haziran 2019 tarihinde İstanbul' da düzenlenen 4. Uluslararası Sağlık Bilimleri ve Yönetim Kongresi'nde bildiri olarak sunulmuştur. Bu çalışma Süleyman Demirel Üniversitesi Bilimsel Araştırma Projeler Koordinasyon Birimince Prof. Dr. Ramazan ERDEM tarafından yürütülen SYL-2018-6902 numaralı ve “Bireylerin Yaşlılık ve Ölüm Algısının Sağlık Hizmeti Kullanımına Etkisi” başlıklı Yüksek Lisans Tez Projesi kapsamında desteklenmiştir.

b İletişim Yazarı: rabiafettahoglu95@gmail.com.

c Öğr. Gör., Kafkas Üniversitesi, ORCID: 0000-0002-5736-7115.

d Prof. Dr., Süleyman Demirel Üniversitesi, ORCID: 0000-0001-6951-3814.
} 


\section{Giriş}

Bilim ve teknolojide kaydedilen gelişmeler sayesinde dünya genelinde bebek ölümlerinde azalmalar olmuş ve insanoğlu daha uzun yaşam sürmeye başlamıştır. Tüm dünyada insanlar artık daha uzun yaşadığından bu durumun sosyolojik hayata yansımaları öne çıkmış ve kurumsallaşan yaşlılık anlayışı günümüzde kendine yer edinmekle birlikte iktisadi piyasaların genç, zinde ve sağlıklı bedenlere duyduğu arzu yaşlıları öteleyen/ikinci plana atan bir yapıyı ortaya çıkarmıştır. Yaşlılık, insan yaşamındaki en son dönem olması sebebiyle önem arz eden bir olgu olsa da artık bir yük olarak görülmeye başlanmıştır.

Sağlık hizmeti kullanımı hem zaruri olması hem de toplum sağlığına etki etmesinden ötürü ele alınan bir konu olmuştur. Bu hizmetlerin yapısı gereği diğer pek çok piyasa şartlarından ayrılmasını sağlayan özellikleri de bulunmaktadır. Bunların yanı sıra literatürde sağlık hizmeti kullanımı ölçen çalışmalarda (İlhan vd., 2006; Ertaş ve Kıraç, 2019) genel olarak polikliniğe, acile, ve aile hekimine başvurma sıklıklarıyla alakalı sorular sorulmaktadır. Ayrıca son bir sene içerisinde kaç kez/defa başvurulduğuna dair elde edilen bilgiler sağlık hizmeti kullanımının ölçülmesinde yarar sağlamaktadır.

Bu çalışmada yaşlılık algısının modern zamanda yaşadığı dönüşüm ele alınmış ve hayatın her alanında var olan bu olgunun sağlık hizmetlerine yansıyan yapısı araştırılmaya çalışılmıştır. Yaşlılığın değişen yapısına rağmen genç bir bireyin dinamikliği ve yaşlının tecrübesi sayesinde daha güzel ve üretken sonuçlar elde edileceği de bir gerçektir. Bu çalışmada bireylerin yaşlılık algısının sağlık hizmeti kullanımı üzerindeki etkisi incelenmiştir.

\section{Yaşlılık ve Yaşlanma Kavramları}

Yaşlanmayla alakalı birçok kavram günlük hayatta bir arada kullanılmaktadır. Öyle ki yaş (age), yaşlılık (old age ve senilty) ve yaşlanma (aging) kavramları aynı anlamda kullanılmasına karşın farklı tanımları içermektedir. Yaş kavramı; doğum tarihini baz alan bir özellik taşıyıp (Parlak vd., 2015: 580) Türk Dil Kurumu (TDK, 2019)'na göre, “doğuştan beri geçen ve y1l birimi ile ölçülen zaman", "hayatın çeşitli evrelerinden her biri, çă̆" ve "bir kurum, bir kuruluş, düzen vb.nin kurulduğundan bu yana geçen zaman" olarak ifade edilmiştir. Yaşlılık ise biyolojik, tarihsel ve sosyo-kültürel anlamda önlenmesi mümkün olmayan ve kendine ait sorunları bünyesinde barındıran bir süreci kapsamaktadır (Konak ve Çiğdem, 2005: 23).

Yaşlanma; çürüme, düzen kaybı, entropinin yükselmesi, ilerleyen yaşa eşlik eden hastalığa ve ölüme karşı giderek artan duyarlılıkla ilişkili ya da sorumlu olan değişikliklerin artan birikimidir. Bu süreç doğası gereği önemli spekülasyonlara konu olmasının yanı sıra elde edilen kanıtlar hücreler ve dokularda sürekli olarak devam eden serbest radikal reaksiyonların yaşlanma sürecinin oluşumunda etkili olduğunu ya da katkıda bulunduğunu göstermiştir (Blagosklonny ve Salon, 2009: 357; Harman, 1981: 7124). Aynı zamanda yaşlanmayı kronolojik, biyolojik, psikolojik ve sosyal yaşlanma diye sınıflandırmak faydalı olacaktır (Hooyman vd., 2015: 5-6):

Kronolojik Yaşlanma: Bir kişinin doğumdan başlayıp yaşadığı yılları temel almaktadır. Biyolojik Yaşlanma: Biyolojik yaşlanma neticesinde vücutta belli fizyolojik değişimler görülmektedir. Akciğer, kalp ve dolaşım sisteminin verimliliğindeki azalmayı ifade etmektedir.

Psikolojik Yaşlanma: Bilişsel yeteneklerde (hafıza, öğrenme, zekâ vb.), duygu durumunda ve uygulanabilir kapasitede meydana gelen değişimleri tanımlamak adına kullanılmaktadır. 
Sosyal Yaşlanma: Bireyin yaşlanması neticesinde değişen rollerinin ailesi, arkadaşları, diğer gayrı resmi destekleri, iş ve gönüllük gibi gerek ücretli gerekse de ücretsiz üretken rollerini kapsamaktadır.

Dünya Sağlık Örgütü (DSÖ)'nün yaşlılık dönemiyle ilgili sınıflandırması ise şu şekildedir (Tümerdem, 2006: 195):

a. 65-75 yaş arası, erken yaşl1lık dönemi

b. 75-85 yaş arası, orta yaşlılık dönemi

c. 85 yaş ve ötesi, ileri yaşlılık dönemi

Yukarıda belirtilen yaş aralıkları DSÖ’́nün kendi ölçütleri olarak düşünülmesi gerektiğinden bir genelleme yapmak doğru olmayabilir. Nitekim Hooyman ve diğerleri (2015: 5) yaşlıyı tanımlamak için küresel standartlar olduğunu belirtmiş ve kendi kitaplarında 65 yaş ve üzeri kişileri yaşlı nüfusa dâhil etmiştir.

İnsan yaşamının son evresi olan yaşlılığın; kendine has özellikleri bulunduğu gibi çocukluk, ergenlik ve yetişkinlik döneminden ayrılmasını sağlayacak unsurlar bu noktada önem arz etmektedir. Öyle ki insanın hayatında meydana gelen değişimlerin yaşlılık döneminde fiziksel, psikolojik ve sosyal etkisi bulunmaktadır. Koca (1994: 9)'ya göre yaşlılık, insanın yaşam eğrisinde son dönemi ifade ettiğinden genç bir insanın hareket kabiliyetiyle yaşlı bir insanınki farklı olmakta ve bu dönemde bir takım fiziksel değişimler meydana gelmektedir. Kronik hastalıkların artış göstermesiyle yaşın ilerlemesi arasında bir bağlantı bulunduğundan bu dönemde hastalıklarla daha sık karşılaşıldığı bilinmektedir. Özellikle de bunlar arasında kalp ve damar hastalıklarının artması, fiziksel hareket yetisinde gerileme, duyu organlarının eski işlevini yitirmesi, davranışların ve reflekslerin eskiye nazaran yavaşlaması, kemiklerde meydana gelen erime ve kireçlemeler sayılmaktadır.

İkinci etki olarak psikolojik değişimler hususunda yaşlılığa değin insanın geçirdiği hayat, ailesi, çevresi ve genel sağlı durumu gibi etkenler bu dönemin psikolojik özelliklerinin oluşmasına etki edebilir. Yaşlı insanların bu dönemde yalnız kalmaları, belli başlı psikolojik hastalıklara yakalanmaları ve daha evvel var olan sosyal çevrelerinden kopmaları psikolojik durumlarını sarsabilir. Örneğin bir bireyin yalnız şekilde yaşlılı̆̆ını geçirmesi aile içinde olana nazaran bu dönemin birey tarafından daha farklı anlam kazanmasına neden olabilir.

Üçüncü etki olarak yaşlılık döneminin en belirgin özellikleri; gençlik ve yetişkinlik döneminde sahip olunan otorite, statü ve rollerin kaybının bireyde meydana getirdiği sosyal değişimlerdir. Bunların yanı sıra toplumsal ayrımcılık, fiziksel yetilerdeki kayıplar, emeklilik ve çevrenin değişimi gibi sebepler bireyin sosyal hayatında değişimler yaşanmasına neden olmaktadır. Diğer yandan aileyle ilişkilerde meydana gelen problemler, bir işini görebilmek için başkalarına ihtiyaç duyma, iş bulmada yaşanan zorluklar, tüketici konumuna gelme, yararlı olmama, arkadaş ve dost ilişkilerinde eskiye nazaran yaşanan eksilmeler de bu dönemde önem kazanan sosyal faktörler arasında yer almaktadır (Kurt, 2008: 24). Bu değişimler neticesinde yaşlı insanın hayatta kendine bir yer edinmesi ve daha evvel aktif şekilde geçirdiği yaşamını devam ettirmesi önem arz etmektedir. Öyle ki pek çok yaşlı insan bu değişimler nedeniyle yaşlılığ kabul etmemektedir.

Değişen ve dönüşen yaşlılık algısına binaen yaşlılıkla ilgilenen bilimler yeni yeni gelişim göstermektedir ve bu açıdan gerontoloji ve geriatriye değinmek gerekli olacaktır. Gerontoloji 
yaşlanma ile alakalı bilimdir ve üç temel bileşenden oluşmaktadır. Gerontoloji yaşlılığı; biyolojik, sosyal ve psikolojik bağlamda ele almaktadır. Bundan dolayı da gerontoloji bu alanların her birinin katkılarının olduğu çok disiplinli bir alan olarak görülmektedir (Victor, 1994: 1). Geriatri ise yaşlılık ve yaşlıların sağlık sorunlarına eğilen bir bilim dalı olarak ortaya çıkmıştır. Buradan hareketle gerontolojinin yaşlanma fizyolojisini inceleyen bir bilim olmasından dolayı geriatriden farklılaştığı görülmektedir. Geriatri; zekânın, soru çözmenin, yaratıcılığın ve hastayla aileler arasında bağın tanımını duygusal boyutta ele almaktadır (Kutsal, 2003: 2).

Konuya bu minvalde bakıldığında yaşlılığın dönüşen yapısının sağlık hizmetleri boyutunda kurumsallaşma noktasında bir anlam kazandığı görülmektedir. Modern çağda meydana gelen teknolojik gelişmeler insanların daha uzun yaşamasını sağlamış ve eskiye kıyasla insanların sağlık hizmeti tüketim alışkanlıkları da değişmiştir. Özellikle de uzun süre yaşamanın sağlık sistemlerine yansıyan bir yönü olduğu ileri sürülebilir. Bilimsel ve teknolojik alanda yaşanan gelişimlerin sağlık hizmetlerini daha yaygın ve ulaşılabilir kıldığını ifade etmek doğru olacaktır. Haliyle bu alandaki tüketim alışkanlıklarında da belli değişimler meydana gelmesi kaçınılmaz olmaktadır.

\section{Geçmişten Günümüze Yaşlılık Algısı}

Yaşlının aile ve toplumdaki konumunun, içinde yaşanılan zamanla ve çevresel etmenlerle yakından bir ilgisi bulunmaktadır (Akın, 2002: 75). Dünyada nüfus hareketlerinde, ekonomik faktörlerde ve aile yapısında meydana gelen kopuşlar yaşlının statüsündeki değişimi meydana getirmiştir. Yaşlı insanlar geleneksel ailelerde olduğu gibi evlatları ve torunlarıyla birlikte yaşamak yerine kurumsallaşan bir yapıda hayatına devam etmektedir. Modern zamandan evvel saygı duyulan, kendisinden belli hususlarda fikirler alınan yaşlı profili yerini günümüzde aksi, huysuz, her şeye karışan ve çok konuşan bir imaja bırakmıştır. Şüphesiz ki bu durumda modern zamanın yaşlılığa bulunduğu atıf etkili olmuştur.

Neolitik dönemden bu yana yerleşik döneme geçilmesi sonucunda tarım faaliyetleri başlamış ve yaşam büyük ölçüde yaşlılar adına kolaylaşmıştır. Yerleşik hayata geçerek toprağ öğrenen insan, sadece tüketmek yerine üretime de vakıf hale gelmiştir. Öyle ki ürettiğini sonrası için saklamış ve ilerde ekonomik gelirini bundan elde edeceği takas yöntemini kullanmıştır. Bundan dolayı ilk insanın sadece yaşamak amacı güderek topladığı yiyecek (bitki) üretilip başka ihtiyaçlara ulaşmada kaynak sağlayan bir işlev görmüştür (Akın, 2002: 75; Akülkü, 2015: 31).

16. ve 17. yüzyıllarda yaşlı bedensel güç kaybına uğrayan kişi olarak tanımlanmış ve aynı zamanda bu dönemlerde yaşlılık, takvimsel yaşla ölçülen bir özellik taşımamıştır. $O$ zamanlarda yaşlılık; ölümün ilk basamağı olarak ele alınmaya başlandığından dönemin edebi eserlerinde bu dönem bütün acımasız ve olumsuz yönleriyle ele alınmıştır (Tufan, 2016: 100). 20. yüzyılda doğum ve ölüm oranlarında yaşanan dramatik değişimler dünyanın 21. yüzyılda hızlı bir şekilde yaşlanmasına neden olmuştur (National Research Council, 2001: 1).

Son dönemlerin nüfus planlaması hareketleri sayesinde yaşlı oranın arttığı bir demografik yapı ortaya çıkmış ve tıpta meydana gelen gelişmeler neticesinde anne ve baba olma yaşının daha ileriye gitmesinin yanı sıra aile planlaması politikaları ve eğitim düzeyinde ortaya çıkan artış gibi nedenler de dünyanın yaşlanmasına etki etmiştir (Ertaylan, 2016: 4). 


\section{Modernleşmeyle Birlikte Yaşlılık Algısı}

Modernleşme; toplumları bir boyuta indirgeyen birbiriyle ilişkili toplumsal değişimlerin bir özeti olarak tanılanmaktadır (Silverstein vd., 1998: 388). Bu tanımdan da hareketle bugünkü yaşlılık algısının üzerinde etkisi olan modernleşmeyi nüfus yapısı, ekonomik faktörler ve aile yapısı gibi etmenleri ele alarak ayrıntılı şekilde irdelemek mümkündür.

\section{Nüfus Yapısındaki Değişim}

Gelişen ve dönüşen dünyada maddi kültür unsurlarının öneminin artması toplumların her manada refah seviyesine ulaşmak adına etkili adımlar atmasını sağlamıştır. Teknolojide meydana gelen yenilikler ve tıptaki gelişmeler; hastalıkların iyileşmesi ve bebek ölüm oranlarının azalmasını sağlamış ve bu sayede ortalama yaşam süresi uzamıştır. Bunlara ilave olarak daha bilinçli bireylerin dengeli beslenme ve spor gibi günlük aktiviteleri hayatında uygulaması da etkili olan faktörler arasında yer almıştır (Taşkesen, 2017: 93). Bunu destekler nitelikte Bulduk (2014: 55) günümüzde sanayi devriminden sonra tıp bilimlerinde kaydedilen ilerlemelerin dünya nüfusunun hızla yaş ortalamasının artmasına neden olduğunu ifade etmiştir.

Nüfusun yaşlanması; yüksek doğurganlık oranlarının azalması ve yüksek ölüm oranlarındaki meydana gelen düşüşten kaynaklanmaktadır. Dünya genelinde meydana gelen bu eğilime "demografik geçiş" adı verilmektedir. Geçiş; ilk olarak küçük çocukların ölüm oranlardaki düşüşle beraber doğurganlığın daha yüksek olduğu bir eğilim seyrettiğinden bu ilk aşamada daha genç bir nüfus yapısı mevcuttur. İkinci aşamanın zaman içinde gerçekleşmesinin yanı sıra farklı ülkelerdeki görülme biçimleri değişik yapıya sahip olmuş ve bütün dünya bölgelerinde doğurganlık azalan bir seyir izlemiştir. Neticede dünya nüfusunun sadece yaşlanması gibi bir durum söz konusu olmamakla birlikte aynı zamanda 21. yüzyılda yaşlı nüfusunun iki katına ulaşması beklenmektedir (Kuné, 2003: 17).

\section{Ekonomik Faktörler}

19. yüzyıla değin tarım ülkesi özelliğini taşıyan İngiltere 70 senede ekonomik alanda elde ettiği gelişmeler sayesinde ilk endüstri toplumunu oluşturmuştur. Neticede köylerden kentlere doğru bir göç akımı başlamış ve şehirleşme olgusu cereyan ettiğinden Sanayi Devrimi yeni bir dönemi ortaya çıkarmıştır. Toplumların sosyal yapılarında değişimler meydana gelmiş ve ülkelerin temelleri bu değişimlerden etkilenmeye başlamıştır. Çekirdek aile olgusu toplumda kendine yer edinmeye başlamasına rağmen o dönemlerde nüfus artışına engel olunamamıştır. Özellikle de çocuklara "çalışma yasağı" gelmediği ve eğitim bilinci bu kadar yaygın olmadığından yaşlı birey aile bütçesine katkı sağlayan bir unsur olarak görülmeye devam edilmiştir (Tufan, 2016: 120).

Bunların yanı sıra politik ekonomi ve yaşlanma arasındaki ilişkiyi ele alan Çatışmacı Yaşlanma Kuramı sosyal kaynakların dağılımındaki eşitsizliklerin her alanda olduğu gibi yaş faktöründe de etkili olduğunu ileri sürmektedir. Kapitalist toplumların temelini maddi üretimin oluşturması bu kuramın ileri sürdükleri arasında yer almaktadır (Kurtkapan, 2017: 62). Diğer yandan köylerden kentlere yaşanan göç insanların sosyal hayatlarına yansımalar meydana getirmiştir. Yaşlı nüfusun ekonomik faaliyetlere uyum sağlaması ya da işgücüne katılım sağlaması zor olmuştur (Türkiye'de Yaşlıların Durumu ve Yaşlanma Ulusal Eylem Planı Uygulama Programı, 2012: 8). Bu bakımdan yaşlı bireylerin sanayileşmiş ekonomide kendine yer edinmesi zor olmuş ve aynı zamanda köyde kendi kendine yeten bir hayatı olan insanların kentteki yaşamsal ihtiyaçlarını karşılamak için daha fazla çalışması gerekmektedir. Ancak 
yaşlı bir insanın metropol şehirlerdeki çalışma hayatına ayak uydurması söz konusu olmamaktadır.

\section{Aile Yapısındaki Değişim}

Modern dönemde sosyo-ekonomik değişimler meydana gelmiş ve bu durumun toplumdaki en büyük yansıması aile yapısında olmuştur. Neticede yaşlı ve aile ilişkileri "sosyal bağlamda bir sorun" olarak ele alınmaya başlanmıştır. Endüstrileşme ve kentleşme süreci geniş aileden çekirdek aileye dönüşümü kaçınılmaz kıldığından gerek kentteki gerekse de kırsalda yaşayan ailede meydana gelen bu değişim yaşlıya saygının azalmasına neden olmuştur (Kurt, 2008: 77).

Bütün bunlardan hareket edilecek olursa aile yapısında meydana gelen bu değişimin yaşlının sosyal rollerine etki ettiği görülmektedir. Daha evvel bilge konumunda yer alan yaşlı birey; çekirdek aile yapısında kendine yer edinemediğinden ötürü yaşlılığın toplumdan dışlanan ve kurumsallaşan yapısı öne çıkmıştır. Aile; bir toplumun özelliklerinin oluşmasında etkili olan önemli bir belirleyici olarak görülmektedir. Bundan ötürü yaşlıya gösterilen saygı yahut algılama biçiminde bunlardan kaynaklanan bir değişim olduğu ileri sürülebilir.

Toplumsal yapıda meydana gelen değişimlerden en büyük etkiyi kentleşme olgusu meydana getirmiştir. Ailede yer alan kişilerin görev ve sorumlulukları yeniden tanımlandığı için yaşlının toplumdaki statüsündeki değişimler kaçınılmaz olmuş ve 1950'lerden sonraki ilk göç hareketlerinden sonra kadın yavaş yavaş çalışma hayatının içine girmiş ve özellikle de 1980'ler kadını geleneksel rollerinden sıyırarak bir tüketici konumuna taşımıştır. İş hayatına giren kadının elde ettiği ekonomik güç, toplumsal bağlamda daha evvel var olan rollerinin (anne, gelin, ev kadını gibi) yerine kendi kazancını elde eden ve kariyer peşinde koşan bir bireye dönüştürmüştür. Haliyle anne ve babanın işe gittiği, çocuğu da kreşteki yetkin kişilerin baktığ1 "aile" yapısı yaygınlık kazanmış ve geleneksel dönemde çocuğa bakma görevi olan yaşlının bu rolü elinden alındığı gibi iş hayatında aktif bulunan kadın yaşlıya bakma rolünden de sıyrılmıştır. Yaşlı kesime bakma görevi de modern zamanların bakıcı ve huzur evi çalışanlarına kaymıştır (Ertaylan, 2016: 5).

\section{Sağlık Hizmeti Kullanımı}

Sağlık hizmeti kullanımı; ihtiyacı olan kimselerin (hastaların) bu hizmetten yararlanması şeklinde tanımlanmaktadır. Bu bakımdan kullanım ölçütlerini belirlemede bazı hususlar öne çıkmaktadır. Kullanılan hizmetinin türü (doktor, diş hekimi, hastane, acil vb.); bakımın sağlandığı alan (ev, muayenehane, hastane, klinik vb.); alınmış olunan bakımın amacı (koruyucu, tedavi edici, rehabilite edici vb.) ve ne zaman olduğu (belli bir zaman içinde ne kadar sıklıkla doktora gidilip gidilmediği) gibi kriterler kıstas olarak kullanılmaktadır (Kaya, 1995: 102).

Sağlık hizmeti kullanımı hakkında Andersen tarafından 1968' de geliştirilen "Sağlık Hizmetleri Kullanımında Davranışsal Modeli" (Behavioral Model of Health Services Utilization) literatürde oldukça geniş bir yer kaplamaktadır. Geliştirilen bu modelde sağlık hizmeti kullanımı üç ana faktör altında incelenmektedir: "Eğilim (predisposing), imkân (enabling) ve ihtiyaç faktörleri (need factors)". Bireyin içinde yaşamakta olduğu toplumun kültürel, sosyal ve ekonomik yapısı, kişilerin sahip oldukları inançlar ve bilgi düzeyleri, yaşanılan ülkedeki sağlık hizmetlerinin ekonomik özellikleri ve sigorta kapsamında sağlanan hizmetler, yetişmiş olunan aile, bireyin sağlık durumu ve kullanıcının sağlığını algılayış düzeyi gibi etmenler sağlık hizmeti kullanıma yön vermektedir (Gökkaya ve Erdem, 2017: 152). 
Sağlık hizmeti kullanımını ele alan çalışmalarda genel olarak araştırmacının amacı önem kazanmaktadır. Literatürde yapılan çalışmalara bakıldığında sağlık hizmeti kullanımını ölçmek amacıyla genel olarak hekime başvurma, diş hekimine başvurma, diğer sağlık personeline başvurma (hemşire, ebe vb.), polikliniğe başvurma, acile başvurma, klinik hizmeti alma, tedavi edici sağlık hizmeti alma, eczaneye başvurma gibi kriterler kullanılmaktadır. Bunların yanı sıra zaman kıstası da sağlık hizmeti kullanımını ölçmek için önemli bir etkendir. Öyle ki "Son bir sene içerisinde kaç kez hekime/acile başvurdunuz?" gibi sorular yine araştırmacının amacına hizmet edecek şekilde sorulmaktadır (Erdem ve Pirinçci, 2003: 40). Araştırmacının amacına binaen belli zaman aralıklarında kişilerin sağlık hizmeti kullanımları ölçülmektedir. Bu sayede belli bir toplumun sağlık hizmeti kullanım alışkanlıkları ortaya konmakta ve değerlendirme yapılabilmektedir.

\section{Yöntem}

Bu bölümde yaşlılık algısıyla ilgili yapılan araştırmanın gereç ve yöntemine yer verilmiş ve neticede elde edilen bulgular üzerinde durulmuştur.

\section{Amaç ve Önem}

Yaşlılık algısının ortaya konulması bakımından modern zamanın yansımalarının göz ardı edilmemesi gerekmektedir. Öyle ki yaşlılık algısı modern zamanda bir takım değişimlere uğrayarak günümüzde sosyal hayat içinde var olmakta ve yaşlılığın kurumsallaşan yapısı bu durumun sağlık hizmetlerine yansıyan yönünü oluşturmaktadır. Yaşlılık dönemi insana ait değilmişçesine kaçınılan ve eksikliklerin olduğu bir dönem olarak düşünülmektedir. Bu çalışmada bireylerin yaşlılık algısının sağlık hizmeti kullanımına etkisi incelenmiştir. Bu çalışmanın problem cümlelerini "bireylerin yaşlılık algısı ve sağlık hizmeti kullanımları nasıldır?", "yaşlılık algısının sağlık hizmeti kullanımı üzerine etkisi var mıdır?" soruları oluşturmaktadır.

\section{Evren ve Örneklem}

$\mathrm{Bu}$ araştırmanın evrenini Isparta il merkezinde ikamet eden 18 yaş üstü bireyler oluşturmaktadır. Medeni Kanunun 9. maddesine göre fiil ehliyetine sahip olan kimse hak edinebilmekte ve Siyasi Partiler Kanunu'nun 11. Maddesine göre 18 yaşını dolduran kimseler medeni ve siyasi haklarını kullanma ehliyetine sahiptir. Özenci (2017: 22)'ye göre 18 yaş ve üzeri bireyler biyolojik ve psikolojik açıdan çocukluğun sonuna gelmiş ve toplumda sorumluluk alabilen bir özelliğe sahiptir. Öyle ki 18 yaş, kişinin bireysel sorumluluk alma ve kanaat ifade edebilmesi açısından önem arz eden bir yaş olarak görülmektedir. Bu açıdan toplumun her kesiminde meydana gelen yaşlılık algısı dönüşümünü anlayabilmek için 18 yaş ve üzeri bireyler örnekleme dâhil edilmiştir. Evrenden kolayda örnekleme yöntemiyle 500 kişiye ulaşılmıştır. Isparta il merkezi nüfusu (TUIK, İl Nüfusu, 2018) 237.000'dir. \%95 güven aralığı ve \%5 hata payı ile bu evrenden 384 kişilik örneklem yeterli olabilmektedir (Yazıcıŏlu ve Erdoğan, 2000: 50).

\section{Veri Toplama Aracı}

Araştırmada veri toplama aracı olarak anket kullanılmıştır. Sosyal bilimler alanında sıklıkla tercih edilen bir veri toplama aracı olması ve istatistiksel analize uygun olması bu yöntemin tercih edilmesinde etkili olmuştur.

Araştırmada veri toplama aracı olarak kullanılan anket formu 3 bölümden oluşmaktadır. Birinci bölümde yer alan Avrupa Yaşlanma Tutumu Anketi (AYTA) (Attitudes of Aging 
Questionnaire)'nin Türkçe'ye uyarlanan Eser ve diğerlerinin (2011) çalışmasından alınmıştır. Bu ölçek 5'li likert tipindendir ve katılımcıların verdikleri cevaplar "Hiç Katılmıyorum" "1", ve "Tamamen Katılıyorum" ise "5" olarak puanlandırılmıştır.

Anket formunun ikinci kısmında "sağlık hizmeti kullanımıyla" ilgili açık uçlu sorular bulunmaktadır. Bu sorular, "Son bir sene içinde herhangi bir sağglk probleminiz sebebiyle poliklinik, acil, aile hekimi, özel hekim, diş hekimi ve eczaneye başvurdunuz mu?", "Son bir sene içinde herhangi bir sağhlk probleminiz sebebiyle hastaneye yattını mı?"şeklindedir. Cevaplar "evet" ve "hayır" olacak şekilde düzenlenmiş ve olumlu cevap verenlerin kaç kez bu hizmetten yararlandıklarını belirtmeleri istenmiştir. Son olarak üçüncü bölümde demografik bilgilere ilişkin yaş, cinsiyet, medeni durum, aylık gelir seviyesi ve eğitim düzeyi hakkında bilgiler sorulmuştur.

\section{Analiz Yöntemi}

Araştırmaya katılan bireylerin demografik değişkenlere verdikleri yanıtlar frekans dağılımı yapılarak analiz edilmiştir. Sağlık hizmeti kullanımına dair verdikleri yanıtların ise frekans dağılımı alınmış ve bu değerlerin ortalama ve standart sapma değerleri analize tabii tutulmuştur. Yaşlılık algısı ifadelerine faktör analizi uygulanmış ve her bir boyuta normallik testi uygulanmış ve basıklık (kurtosis) ve çarpıklık (skewness) değerleri bulunmuştur. Araştırmacı tarafından uzman kişilerin görüşleri alınarak "Avrupa Yaşlanma Tutumu Anketi'nde" yer alan ifadelerde değişikliğe gidilmiştir. Avrupa Yaşlanma Tutumu Anketi'nin sorularında halktan her yaş kesimine sorabilmek adına bir takım düzenlemeler yapılmıştır. Yaşlılık algısı boyutlarının sağlık hizmeti kullanımına etkisi çoklu regresyon yöntemlerinden backward analiziyle incelenmiştir.

\section{Bulgular}

$\mathrm{Bu}$ başlık altında toplanan verilerden elde edilen bulgular yorumlanmıştır. Araştırma kapsamındaki bireylerin demografik değişkenlere göre dağılımı Tablo 1'de gösterilmektedir.

Tablo 1. Bireylerin Demografik Değişkenlere Göre Dağılımı

\begin{tabular}{|l|c|c|}
\hline \multicolumn{1}{|c|}{ Değişkenler } & N & Yüzde \\
\hline Yaş (Yil) & 277 & 55.4 \\
\hline-29 & 49 & 9.8 \\
\hline $30-39$ & 54 & 10.8 \\
\hline $40-49$ & 31 & 6.2 \\
\hline $50-59$ & 89 & 17.8 \\
\hline $60+$ & 244 & 48.8 \\
\hline Cinsiyet & 256 & 51.2 \\
\hline Kadın & \multicolumn{2}{l|}{} \\
\hline Erkek & 214 & 42.8 \\
\hline Medeni Durum & 286 & 57.2 \\
\hline Evli & 265 & 53.0 \\
\hline Evli Değil & 124 & 24.8 \\
\hline Gelir Seviyesi (TL) & 51 & 10.2 \\
\hline-1.999 & 60 & 12.0 \\
\hline $2.000-2.999$ & \multicolumn{2}{l|}{} \\
\hline $3.000-3.999$ &
\end{tabular}


Tablo 2. Bireylerin Demografik Değişkenlere Göre Dağılımı (Devamı)

\begin{tabular}{|l|c|c|}
\hline Ĕ̆itim Düzeyi & \multicolumn{1}{l|}{} \\
\hline İlköğretim & 136 & 16.4 \\
\hline Lise & 282 & 27.2 \\
\hline Üniversite & $\mathbf{5 0 0}$ & 56.4 \\
\hline Toplam & $\mathbf{1 0 0}$ \\
\hline
\end{tabular}

Tablo 1'de görüleceği üzere araştırmaya katılanların \%55,4'ünü 29 yaş ve altındakiler oluşturmuştur. 30-39 yaş grubu toplam katılımcıların \%9,8'i iken 40-49 \%10.8'i olmuştur. 5059 yaş aralığındaki kişilerin toplam katılımcılar içindeki payı \%6.2' dir. Son olarak araştırmaya katılan 60 yaş ve üzeri bireyler toplam katılımcı sayısının \%17,8'dir. Katılımcıların \%48.8'i kadın iken geriye kalan \%51.2'si erkektir. Katılımcıların yarısından fazlasının (\%57.2) evli olmadığı görülmektedir.

Katılımcıların gelir seviyesine göre gruplandırılmalarında yarısından fazlasının 1.999 TL ve altı gelire sahip olduğu görülmektedir. 2.000-2.999 TL gelir seviyesinde yer alanlar \%24,8, 3.000-3.999 TL grubunda bulunanlar \%10,2 ve 4.000L ve üzeri gelir elde edenler ise $\% 12$ 'dir. Katılımcıların \%16.4'ü ilköğretim, \%27.2'si lise ve geriye kalan \%56.4'ünün üniversite mezunu oldukları görülmektedir.

\section{Sağlık Hizmeti Kullanımına İlişkin Bulgular}

Tablo 2' de katılımcıların sağlık hizmeti almak için hekime başvurma sayıları ifade edilmiştir.

Tablo 2. Sağlık Hizmeti Kullanımı Tablosu

\begin{tabular}{|l|c|c|c|c|}
\hline \multirow{2}{*}{ Sağlık Hizmeti Kullanımı } & \multicolumn{2}{|c|}{ Evet } & \multicolumn{2}{c|}{ Hayır } \\
\cline { 2 - 5 } & $\mathbf{N}$ & $\mathbf{\%}$ & $\mathbf{N}$ & $\mathbf{\%}$ \\
\hline Polikliniğe Başvurma & 371 & 74.2 & 129 & 25.8 \\
\hline Acil Servise Başvurma & 233 & 46.6 & 267 & 53.4 \\
\hline Aile Hekimine Başvurma & 247 & 49.4 & 253 & 50.6 \\
\hline Özel Hekime Başvurma & 133 & 26.6 & 367 & 73.4 \\
\hline Diş Hekimine Başvurma & 199 & 39.8 & 301 & 60.2 \\
\hline Klinik Yatışı & 54 & 10.8 & 446 & 89.2 \\
\hline Eczaneye Başvurma & 387 & 77.4 & 113 & 22.6 \\
\hline
\end{tabular}

Tablo 2' de göre katılımcılardan son bir sene içerisinde polikliniğe başvuranlar \%74.2 (371) iken kullanmadığını belirtenler \%25.8 (129)'dir. Acilden sağlık hizmeti alanlar \%46.6 (233) olup almadığını belirtenler katılımcıların yarısından daha fazlasıdır. Aile hekiminden hizmet aldığını ifade eden kesim \%49.4 (247) iken bu hizmeti kullanmayanlar \%50.6 (253)'dır. Katılımcıların oldukça yüksek bir kısmı (\%73.4) özel hekime başvurmamıştır. Bunun yanı sıra diş hekimine başvuranlar \%39.8 (199) iken bu hizmeti kullanmayanlar \%60.2 (301)'dir. Yataklı tedavi hizmeti aldığını ifade edenler \%10.8 (54)'dir. Diğer bir ifadeyle katılımcıların oldukça yüksek bir kısmı (\%89.2) bu hizmetten yararlanmamıştır. Son olarak eczaneye başvuran kesim \%77.4 (387) iken kullanmayanlar \%22.6 (113)'dır. Bireylere sağlık hizmeti almak için hekime başvurma sayıları sorulduğunda verilen cevaplar Tablo 3 'te ifade edilmiştir.

Tablo 3. Sağlık Hizmeti Kullanım Sayıları

\begin{tabular}{|l|c|c|c|c|c|}
\hline Sağlık Hizmeti & N & Minimum & Maximum & $\overline{\boldsymbol{X}}$ & SS \\
\hline Poliklinik & 500 & $0^{*}$ & 27 & 2.91 & 2.944 \\
\hline Acil & 500 & $0^{*}$ & 10 & 1.84 & 1.484 \\
\hline
\end{tabular}


Tablo 3. Sağlık Hizmeti Kullanım Sayıları (Devamı)

\begin{tabular}{|l|c|c|c|c|c|}
\hline Aile Hekimi & 500 & $0^{*}$ & 16 & 2.54 & 2.515 \\
\hline Özel Hekim & 500 & $0^{*}$ & 6 & 1.62 & 1.029 \\
\hline Diş Hekimi & 500 & $0^{*}$ & 10 & 1.81 & 1.564 \\
\hline Kliniğe Yatış & 500 & $0^{*}$ & 3 & 1.25 & 0.483 \\
\hline Eczane & 500 & $0^{*}$ & 32 & 3.70 & 4.079 \\
\hline
\end{tabular}

* Sağlık hizmetini hiç kullanmayanlar/almayanlar.

Son bir sene içerisinde katılımcılar poliklinik hizmetini en az 0 en çok 27 kez kullanmıştır ve bu hizmeti kullananların ortalaması 2.91 olarak bulunmuştur. Aynı şekilde acil sağlık hizmeti en az 0 en fazla $10 \mathrm{kez}$ kullanışmıs ve hizmetten yararlananların ortalaması 1.84 olmuştur. Katılımclar aile hekimliği hizmetini en az 0 en fazla 15 kez kullanmış ve bunun ortalaması 2.54 olarak belirlenmiştir. Özel hekim başvurular en az 0 en fazla 6 kez olmuş ve hizmet alanların ortalaması 1.62 olarak saptanmıştır. Katılımcılar, diş hekimine en az 0 en fazla $10 \mathrm{kez}$ başvurmuş ve ortalama değeri 1.81 olarak bulunmuştur. Klinik hizmeti kullanımı en az 0 en fazla 3 kez olarak beyan edilmiş ve ortalama 1.25 olarak tespit edilmiştir. Son olarak da eczane hizmeti kullanımıyla alakalı soruya en az 0 en fazla 32 cevabı verilmiş ve hizmeti kullananların ortalaması 3.70 olmuştur. Bu bulgular yorumlandığında eczane hizmeti kullanımının bu kadar yüksek çıkmasının nedeniyse poliklinik, acil, aile hekimi gibi sağlık hizmetlerine başvuran bireylerin daha sonrasında ilaç almak için eczaneye başvurmasından kaynaklı olduğu görülmektedir. Diğer yandan bireylerin aile hekimliği hizmetinden de yararlandığı ancak polikliniğe başvurma sayılarının daha fazla olduğu tespit edilmiştir. Bunların yanı sıra katılımcıların ancak \%10'u son bir sene içerisinde klinik hizmeti kullanmıştır. Bu minvalde yatakta tedavi hizmetlerinin poliklinik, acil, aile hekimi, diş hekimi, özel hekim ve eczane hizmetlerine göre en az kullanılan hizmet türü olduğu saptanmıştır.

\section{Yaşlılık Algısı İfadelerinin Faktör Analizi}

$\mathrm{Bu}$ bölümde yaşlılık algısı ölçeğinin faktör analizlerine yer verilmiştir. Öncelikle yapılacak olan test Kaiser-Meyer-Olkin testi ve Bartlett's testidir. KMO ölçüsü, k maddeden oluşmuş olan ölçeğin fenomeni ölçmedeki yeterliliğini ortaya koymaktadır. Bu değerin 0.50'den daha büyük bir değere sahip olması gerekmektedir. Ayrıca bu değer 1'e yaklaştıkça fenomenin ölçülme gücü yüksek yeterliliğe sahip olmaktadır. Bartlett's testi ise ölçeğin kendi maddelerinin aralarında uyumlu olup olmadığını ortaya koymaktadır. Bu değer $p>0.05$ ise ölçekteki maddeler birbiriyle ilgisiz veya yeterli korelasyona sahip değildir. $\mathrm{p}<0.05$ ise ölçeğin alt boyutları ölçmede etkin bir yeterliliğe sahip olduğunu göstermektedir (Aksu vd., 2017: 148).

Tablo 4. Yaşlılık Alg1sı Ölçeği KMO ve Bartlett's Test Sonucu

\begin{tabular}{|l|l|l|}
\hline \multicolumn{3}{|c|}{ KMO ve Bartlett's Test } \\
\hline $\begin{array}{l}\text { Kaiser-Meyer-Olkin Measure of } \\
\text { SamplingAdequacy. }\end{array}$ & \multicolumn{2}{|c|}{0.757} \\
\hline Bartlett's Test of Sphericity & Df. & 136 \\
\cline { 2 - 3 } & Sig. & 0.000 \\
\hline
\end{tabular}

Yaşlılık algısı ifadelerine uygulanan KMO testi sonucunda değer 0.757 çımış ve KMO değerinin 0.7 'den büyük olması anketin faktör analizi için geçerlilik düzeyinin iyi olduğunu göstermektedir. Bartlett's testi sonucuna bakıldığında (Sig.=0.000, p<0.05) ifadelerin anlamlı olduğu tabloda görülmektedir. 
Tablo 5'te Yaşlılık Algısı Ölçeğinin faktör analizi sonuçları yer almaktadır.

Tablo 5. Yaşlılık Algısına Dair İfadelerin Faktör Analizi Sonuçları

\begin{tabular}{|c|c|c|c|}
\hline Faktörler & $\begin{array}{l}\text { Faktör } \\
\text { Yükleri }\end{array}$ & $\begin{array}{c}\text { Açlklanan } \\
\text { Varyans }\end{array}$ & $\begin{array}{c}\text { Cronbach's } \\
\text { Alpha }\end{array}$ \\
\hline \multicolumn{4}{|l|}{ Faktör 1: Psikososyal Kayıp } \\
\hline 27. Yaşlılık yalnızlık zamanıdır. & 0.651 & \multirow{8}{*}{16.844} & \multirow{8}{*}{0.729} \\
\hline 30. Yaşlılık hayatın keyif kaçıran (içe kapanma) dönemidir. & 0.671 & & \\
\hline $\begin{array}{l}\text { 33. Yaşlıların kendi duyguları hakkında konuşması daha } \\
\text { zordur. }\end{array}$ & 0.482 & & \\
\hline $\begin{array}{l}\text { 36. İleri yaşı, maddi ve manevi kayıpların olduğu zaman } \\
\text { olarak görüyorum. }\end{array}$ & 0.552 & & \\
\hline 39. Yaşlandıkça fiziksel bağımsızlık kaybedilir. & 0.470 & & \\
\hline 41. Yaşlılıkta yeni arkadaşlar bulmak daha zordur. & 0.578 & & \\
\hline 44. Yaşlılıkta kişi kendini toplumdan dışlanmış hisseder. & 0.643 & & \\
\hline $\begin{array}{l}\text { 46. Yaşlılar, yaşından ötürü kendini bazı şeylerden dışlanmış } \\
\text { hisseder. }\end{array}$ & 0.579 & & \\
\hline \multicolumn{4}{|l|}{ Faktör 2: Pozitif Değerlendirme } \\
\hline 25. İnsanlar yaşlandıkça yaşamla daha iyi başa çıkabilir. & 0.681 & \multirow{3}{*}{10.576} & \multirow{3}{*}{0.649} \\
\hline 26. Yaşlanmak bir ayrıcalıktır. & 0.822 & & \\
\hline 29. Yaşlanmakla ilgili pek çok hoşa giden (güzel) şey vardır. & 0.681 & & \\
\hline \multicolumn{4}{|l|}{ Faktör 3: Olumlu Beklentiler Boyutu } \\
\hline 32. Yaşlı olmak sanıldığından daha kolaydır. & 0.628 & \multirow{4}{*}{10.366} & \multirow{4}{*}{0.552} \\
\hline $\begin{array}{l}\text { 38. Yaşlıların, yaşlarından beklenilenden daha fazla enerjisi } \\
\text { vardır. }\end{array}$ & 0.663 & & \\
\hline $\begin{array}{l}\text { 40. Yaşlıların fiziksel sağlık sorunları yapmak istediklerine } \\
\text { engel olmaz. }\end{array}$ & 0.618 & & \\
\hline 47. Yaşlıların sağlığı kendi beklentilerinden daha iyidir. & 0.622 & & \\
\hline \multicolumn{4}{|l|}{ Faktör 4: Tecrübe ve Örnek Olma } \\
\hline $\begin{array}{l}\text { 42. Yaşlı bir insanın tecrübeleri ve kazandıklarını gençlere } \\
\text { aktarması çok önemlidir. }\end{array}$ & 0.790 & \multirow[t]{2}{*}{10.038} & \multirow[t]{2}{*}{0.620} \\
\hline 45. Yaşlılık gençlere iyi örnek olmayı gerektiren bir dönemdir. & 0.790 & & \\
\hline
\end{tabular}

Faktör analizinde Varimax döndürme yöntemi kullanılmıştır. Bu anket ifadelerine uygulanan faktör analizi sonucunda toplam 4 boyut elde edilmiştir. Elde edilen boyutlar "psikososyal kayıp", "pozitif değerlendirme", "olumlu beklentiler" ve "tecrübe ve örnek olma" olarak tabloda görülmektedir. Ankette yer alan 27., 30., 33., 36., 39., 41., 44. ve 46. ifadeler "psikososyal kayıр"; 25., 26. ve 29. ifadeler "pozitif değerlendirme"; 32., 38., 40. ve 47. ifadeler "olumlu beklentiler"; 42. ve 45. ifadeler "tecrübe ve örnek olma" boyutunu kapsamaktır.

Birinci faktör olan "psikososyal kayıp" boyutunun açıkladığı varyans, \%16.844 olup Cronbach's Alpha değeri 0.729 olarak bulunmuştur. Benzer şekilde "pozitif değerlendirme" (ikinci faktör) boyutunun açıkladı̆̆ı varyans, \%10.576 olup Cronbach's Alpha değeri 0.649 'dur. Üçüncü faktörün (olumlu beklentiler boyutunun) açıkladığı varyans, \%10.366 olup Cronbach's Alpha değeri 0.552 olarak tespit edilmiştir. Dördüncü faktör olan "tecrübe ve örnek olma” boyutunun açıkladığı varyans, \%10.038 olup Cronbach's Alpha değeri 0.620'dir.

Anketin orijinal halinde 3 boyut varken bu çalışmada yapılan faktör analizi sonucunda 4 boyuta ulaşılmıştır. Ankette yer alan 28., 31., 34., 35., 37., 43. ve 48. ifadeler birden fazla faktör altında toplandıkları için analizden çıkartılmıştır. 


\section{Yaşlılık Algısı Boyutlarının Psikometrik Özellikleri}

Bu başlık altında yaşlılık algısı boyutlarının psikometrik özellikleri ele alınmıştır. Cronbach's Alpha değerinin güvenilirlik değerlendirmesini Özdamar (2017: 113-114) eserinde; $0.50 \leq K R 20<0.60$ değerinin düşük güvenilirliğe sahip olduğunu prototip ölçek olarak kullanılabileceğini ancak geliştirilmesi gerektiğini ifade etmiştir. $0.60 \leq K R 20<0.70$ değerini yeterli güvenilirlik; $0.70 \leq K R 20<0.90$ değerinin yüksek güvenilirlik ve KR20 $\geq 0.90$ ' 1 çok yüksek güvenilirlik düzeyinde olduğunu ortaya koymuştur. Boyutların psikometrik özellikleri Tablo 6 'da ifade edilmiştir.

Tablo 6. Boyutların Psikometrik Özellikleri

\begin{tabular}{|c|c|c|c|c|c|c|c|c|}
\hline & \multirow[b]{2}{*}{ Boyutlar } & \multirow[b]{2}{*}{$\begin{array}{l}\text { İfade } \\
\text { Sayısı }\end{array}$} & \multirow[b]{2}{*}{ Max/Min } & \multirow[b]{2}{*}{$\begin{array}{c}\text { Cronbach's } \\
\text { Alpha }\end{array}$} & \multirow[b]{2}{*}{$\bar{X}$} & \multirow[b]{2}{*}{ SS } & \multicolumn{2}{|c|}{ Normallik Testi } \\
\hline & & & & & & & $\begin{array}{l}\text { Kurtosis } \\
\text { (Basıklık) }\end{array}$ & $\begin{array}{l}\text { Skewness } \\
\text { (Çarpıklık) }\end{array}$ \\
\hline \multirow{4}{*}{$\begin{array}{c}\text { Yaşlılık } \\
\text { Algısı }\end{array}$} & Psikososyal Kayıp & 8 & $1-5$ & 0.729 & 2.879 & 0.757 & -0.228 & -0.320 \\
\hline & \begin{tabular}{|l} 
Pozitif \\
Değerlendirme
\end{tabular} & 3 & $1-5$ & 0.649 & 3.025 & 1.036 & -0.045 & -0.639 \\
\hline & Olumlu Beklentiler & 4 & $1-5$ & 0.552 & 2.746 & 0.803 & 0.012 & -0.398 \\
\hline & $\begin{array}{l}\text { Tecrübe ve Örnek } \\
\text { Olma }\end{array}$ & 2 & $1-5$ & 0.620 & 4.151 & 0.925 & -1.132 & 0.826 \\
\hline
\end{tabular}

Yaşlılık Algısı Ölçeğinde bulunan boyutlar şu şekildedir:

Psikososyal Kayıp: Bu boyutta yaşlılık; hayatın sonuna doğru maddi ve manevi kayıpların olduğu bir zaman dilimi olarak düşünülmektedir. Özdamar (2017: 113-114)'a göre boyut yüksek düzeyde güvenilir (0.729) bulunmuştur.

Pozitif Değerlendirme: Bu boyutta yaşlılığın pozitif yönlerine dikkat çekilmektedir. Boyutun güvenilirlik derecesi (0.649) yeterli bulunmuştur.

Olumlu Beklentiler Boyutu: Bu boyutta 3 ifade bulunmakta ve aynı zamanda yaşlılıktan beklenenlerin olumlu yönlerine vurgu yapılmaktadır. Boyut düşük güvenilirliğe sahiptir (0.552).

Tecrübe ve Örnek Olma: Bu boyut yer alan ifadeler yaşlılı̆̆ın gençlere iyi örnek olmayı gerektiren bir dönem olduğunu vurgulamaktadır. Boyutun güvenilirlik derecesi $(0.620)$ yeterli düzeydedir.

\section{Yaşlılık Algısının Sağlık Hizmeti Kullanımına Etkisi}

$\mathrm{Bu}$ başlık altında yaşlılık algısı boyutlarının sağlık hizmeti kullanımı üzerindeki etkisi incelenmiş ve çoklu regresyon analizi yöntemlerinden olan backward analizi kullanılmıştır. Bu analiz türünde yapılan işlem "İlk aşamada model içine tüm değişkenler dâhil edilir. Daha sonraki kademelerde her defasında bir tane olmak üzere en düşük kısmi F değerine sahip olan bağımsız değişken $(X)$ atılmak sureti ile işleme devam edilir. Atılan değişkenin katkısı her seferinde test edilir. Atılan değişkenin katkısı istatistiki olarak önemli ise atma işlemi gerçekleştirilmez ve işlem orada durdurulur." şu şekilde açılamaktadır (Efe vd., 2000: 168). Yaşlılık algısının sağlık hizmeti kullanımı üzerindeki etkisinin incelendiği tablolarda belirtilen $\mathrm{X}_{1}$ "psikososyal kayıp", $\mathrm{X}_{2}$ "pozitif değerlendirme", $\mathrm{X}_{3}$ "olumlu beklentiler" ve $\mathrm{X}_{4}$ "tecrübe ve örnek olma" boyutunu ifade etmektedir. 
Tablo 7. Yaşlılık Algısının Poliklinik Hizmeti Kullanımına Etkisi

\begin{tabular}{|c|c|c|c|c|c|c|c|}
\hline Model & \multicolumn{2}{|c|}{$\mathbf{R}$} & \multicolumn{3}{|l|}{$\mathbf{R}^{2}$} & $\begin{array}{l}\text { Düzeltilmiş } \\
\qquad \mathbf{R}^{2}\end{array}$ & $\begin{array}{l}\text { Standart } \\
\text { Hatanın } \\
\text { Tahmini }\end{array}$ \\
\hline$X_{1}$ & \multicolumn{2}{|c|}{0.074} & \multicolumn{3}{|l|}{0.006} & 0.004 & 2.831 \\
\hline \multirow[t]{2}{*}{ Model } & \multicolumn{2}{|c|}{$\begin{array}{c}\text { Standartlaştırılmamış } \\
\text { Katsayılar } \\
\end{array}$} & \multirow{2}{*}{\begin{tabular}{|c|}
$\begin{array}{c}\text { Standartlaştırılmış } \\
\text { Katsayılar }\end{array}$ \\
Beta \\
\end{tabular}} & \multirow{2}{*}{ F } & \multirow{2}{*}{ p } & \multirow{2}{*}{$\mathbf{t}$} & \multirow{2}{*}{ p } \\
\hline & B & $\begin{array}{l}\text { Standart } \\
\text { Hata }\end{array}$ & & & & & \\
\hline 1 Sabit & 1.363 & 0.824 & & \multirow{5}{*}{0.987} & \multirow{5}{*}{0.414} & 1.654 & 0.099 \\
\hline$X_{1}$ & 0.269 & 0.170 & 0.072 & & & 1.586 & 0.113 \\
\hline$x_{2}$ & -0.048 & 0.135 & -0.017 & & & -0.353 & 0.724 \\
\hline $\mathrm{x}$ & 0.168 & 0.174 & 0.048 & & & 0.966 & 0.335 \\
\hline $\begin{array}{l}\lambda_{3} \\
X_{4}\end{array}$ & -0.072 & 0.138 & -0.023 & & & -0.521 & 0.602 \\
\hline 2 Sabit & 1.312 & 0.810 & & \multirow{4}{*}{1.276} & \multirow{4}{*}{0.282} & 1.619 & 0.106 \\
\hline $\mathrm{X}_{1}$ & 0.265 & 0.169 & 0.071 & & & 1.566 & 0.118 \\
\hline$X_{3}$ & 0.144 & 0.160 & 0.041 & & & 0.901 & 0.368 \\
\hline $\mathrm{X}_{4}$ & -0.076 & 0.138 & -0.025 & & & -0.549 & 0.583 \\
\hline 3 Sabit & 1.028 & 0.623 & & \multirow{3}{*}{1.767} & \multirow{3}{*}{0.172} & 1.650 & 0.100 \\
\hline$X_{1}$ & 0.260 & 0.169 & 0.069 & & & 1.540 & 0.124 \\
\hline$X_{3}$ & 0.138 & 0.159 & 0.039 & & & 0.869 & 0.385 \\
\hline \multirow[t]{2}{*}{$4 \quad$ Sabit } & 1.353 & 0.498 & & & & 2.716 & 0.007 \\
\hline & 0.279 & 0.167 & 0.074 & 2.779 & 0.096 & 1.667 & 0.096 \\
\hline
\end{tabular}

Backward analizine göre, poliklinik hizmeti kullanımındaki değişimin $\% 0.6$ 'sının $\left(R^{2}=0.006\right)$ bağımsız değişkenlerden "psikososyal kayıp" faktörü tarafından açıklandığı Tablo 7'de gösterilmiştir. Bunun yanı sıra modelin açıklayıcı gücünün anlamlılığı bakımından yeterli olmadığı görülmüştür $(\mathrm{F}=2.779$, $\mathrm{p}=0.096)$. Bu minvalde "psikososyal kayıp" boyutunun poliklinik hizmeti kullanımı üzerinde pozitif yönlü bir etkiye sebep olduğu ancak bu etkinin istatistiksel olarak anlamlı olmadığı tespit edilmiştir. Yani katılımcıların bu dönemi kayıpların olduğu bir dönem olarak algılamamasından ötürü poliklinik hizmetinden daha az ya da daha fazla yararlanma gibi bir eğilimleri saptanmamıştır.

Tablo 8. Yaşlılık Algısının Acil Sağl1k Hizmeti Kullanımına Etkisi

\begin{tabular}{|c|c|c|c|c|c|c|c|}
\hline Model & \multicolumn{2}{|c|}{$\mathbf{R}$} & \multicolumn{3}{|l|}{$\mathbf{R}^{2}$} & $\begin{array}{c}\text { Düzeltilmiş } \\
\mathbf{R}^{2}\end{array}$ & $\begin{array}{l}\text { Standart } \\
\text { Hatanın } \\
\text { Tahmini }\end{array}$ \\
\hline & \multicolumn{2}{|c|}{0.000} & \multicolumn{3}{|l|}{0.000} & 0.000 & 1.360 \\
\hline \multirow[t]{2}{*}{ Model } & \multicolumn{2}{|c|}{$\begin{array}{c}\text { Standartlaştırılmamış } \\
\text { Katsayılar }\end{array}$} & $\begin{array}{c}\text { Standartlaştırılmış } \\
\text { Katsayılar }\end{array}$ & & & & \\
\hline & B & $\begin{array}{l}\text { Standart } \\
\text { Hata }\end{array}$ & Beta & $\mathbf{F}$ & $p$ & $\mathbf{t}$ & $\mathbf{p}$ \\
\hline
\end{tabular}


Tablo 8. Yaşlılık Algısının Acil Sağlık Hizmeti Kullanımına Etkisi (Devamı)

\begin{tabular}{|cc|c|c|c|c|c|c|c|}
\hline 1 & Sabit & 1.389 & 0.394 & & & & 3.523 & 0.000 \\
& & & & & & \\
& $\mathrm{X}_{1}$ & -0.099 & 0.081 & -0.055 & 1.407 & 0.231 & -1.220 & 0.223 \\
& $\mathrm{X}_{2}$ & -0.096 & 0.065 & -0.073 & & & -1.482 & 0.139 \\
& $\mathrm{X}_{3}$ & 0.109 & 0.083 & 0.064 & & & 1.311 & 0.191 \\
& $\mathrm{X}_{4}$ & -0.065 & 0.066 & -0.044 & & & -0.984 & 0.325 \\
\hline 2 & Sabit & 1.151 & 0.311 & & & & 3.698 & 0.000 \\
& & & & & & & & \\
& $\mathrm{X}_{1}$ & -0.103 & 0.081 & -0.057 & 1.553 & 0.200 & -1.270 & 0.205 \\
& $\mathrm{X}_{2}$ & -0.100 & 0.064 & -0.076 & & & -1.557 & 0.120 \\
& $\mathrm{X}_{3}$ & 0.107 & 0.083 & 0.063 & & & 1.284 & 0.200 \\
\hline 3 & Sabit & 0.898 & 0.239 & & & & 3.751 & 0.000 \\
& & & & & & & & \\
& $\mathrm{X}_{2}$ & -0.106 & 0.064 & -0.081 & 1.521 & 0.220 & -1.655 & 0.099 \\
& $\mathrm{X}_{3}$ & 0.097 & 0.083 & 0.057 & & & 1.175 & 0.241 \\
\hline 4 & Sabit & 1.073 & 0.188 & & & & 5.713 & 0.000 \\
& & & & & & & \\
& $\mathrm{X}_{2}$ & -0.076 & 0.059 & -0.058 & 1.160 & 0.198 & -1.288 & 0.198 \\
\hline
\end{tabular}

Tablo 8'e göre modelin açıklayıcı gücü istatistiksel olarak anlamsız çıkmıştır (F=1.160, $\mathrm{p}=0.198)$. Bu açıdan yaşlılık algısı boyutlarının acil sağlık hizmeti kullanımı üzerinde bir etkisinin olmadığı görülmüştür. Buradan şu sonuca ulaşılmaktadır; katılımcıların yaşlılığı kayıpların olduğu bir dönem olarak görmeleri, bu döneme dair pozitif bir bakış açısı içinde olmaları, yaşlılığa dair olumlu beklentilerinin olması ve tecrübe olunası bir dönem şeklinde görmelerinin acil sağlık hizmeti kullanımına etkisi bunmamıştır. Bu minvalde acil sağlık hizmetinin zaruri bir hizmet olmasından ötürü bu algının etkilenmemesi doğal karşılanabilir.

Tablo 9. Yaşlılık Algısının Aile Hekimliği Hizmeti Kullanımına Etkisi

\begin{tabular}{|c|c|c|c|c|c|c|c|c|}
\hline \multicolumn{2}{|c|}{ Model } & \multicolumn{2}{|c|}{$\mathbf{R}$} & \multicolumn{3}{|l|}{$\mathbf{R}^{2}$} & $\begin{array}{l}\text { Düzeltilmiş } \\
\qquad \mathbf{R}^{2}\end{array}$ & $\begin{array}{l}\text { Standart } \\
\text { Hatanın } \\
\text { Tahmini }\end{array}$ \\
\hline & $\begin{array}{l}X_{1} \\
X_{2}\end{array}$ & \multicolumn{2}{|c|}{0.147} & \multicolumn{3}{|c|}{0.022} & 0.018 & 2.147 \\
\hline \multirow{2}{*}{\multicolumn{2}{|c|}{ Model }} & \multicolumn{2}{|c|}{$\begin{array}{c}\text { Standartlaştırılmamış } \\
\text { Katsayılar }\end{array}$} & $\begin{array}{c}\text { Standartlaştırılmış } \\
\text { Katsayılar }\end{array}$ & \multirow{2}{*}{ F } & \multirow{2}{*}{$p$} & \multirow{2}{*}{$t$} & \multirow{2}{*}{$p$} \\
\hline & & B & $\begin{array}{c}\text { Standart } \\
\text { Hata }\end{array}$ & Beta & & & & \\
\hline & Sabit & -0.149 & 0.624 & & \multirow{5}{*}{3.235} & \multirow{5}{*}{0.012} & -0.239 & 0.811 \\
\hline & $X_{1}$ & 0.291 & 0.128 & 0.102 & & & 2.267 & 0.024 \\
\hline & $X_{2}$ & 0.152 & 0.102 & 0.073 & & & 1.488 & 0.137 \\
\hline & $X_{3}$ & 0.153 & 0.132 & 0.057 & & & 1.167 & 0.244 \\
\hline & $X_{4}$ & -0.080 & 0.105 & -0.034 & & & -0.762 & 0.447 \\
\hline & Sabit & -0.441 & 0.492 & & \multirow{4}{*}{4.124} & \multirow{4}{*}{0.007} & -0.896 & 0.371 \\
\hline & $X_{1}$ & 0.286 & 0.128 & 0.100 & & & 2.233 & 0.026 \\
\hline & $X_{2}$ & 0.146 & 0.102 & 0.070 & & & 1.437 & 0.151 \\
\hline & $X_{3}$ & 0.151 & 0.131 & 0.056 & & & 1.147 & 0.252 \\
\hline
\end{tabular}


Tablo 9. Yaşlılık Algısının Aile Hekimliği Hizmeti Kullanımına Etkisi (Devamı)

\begin{tabular}{|rc|c|c|c|c|c|c|c|}
\hline 3 & Sabit & -0.205 & 0.447 & & & & -0.458 & 0.647 \\
& & & & & & & & \\
& $\mathrm{X}_{1}$ & 0.300 & 0.128 & 0.105 & & & 2.344 & 0.019 \\
$\mathrm{X}_{2}$ & 0.192 & 0.093 & 0.092 & 5.524 & 0.004 & 2.060 & 0.040 \\
\hline
\end{tabular}

Aile hekimliği sağlık hizmeti kullanımındaki değişimin \%2.2'si $\left(R^{2}=0.022\right)$ bağımsız değiş̧kenlerden "psikososyal kayıp" ve "pozitif değerlendirme" faktörü tarafından açıklandığı ve modelin açıklayıcı gücünün anlamlılığı bakımından bir problem olmadığı Tablo 9'da gösterilmiştir ( $\mathrm{F}=5.524, \mathrm{p}=0.004)$. Bu açıdan "psikososyal kayıp" ve "pozitif değerlendirme" boyutlarının aile hekimliği sağlık hizmeti kullanımı üzerinde pozitif yönlü bir etkisinin olduğu ve bu etkinin istatistiksel olarak anlamlı olduğu sonucuna varılmıştır. Bu bakımdan bireylerin yaşlılıktan kaçınmak/geciktirmek/sağlığına dikkat etmek adına aile hekimine daha fazla başvurduğu söylenebilir. Bunun yanı sıra bireylerin, yaşlılığa dair değerlendirmeleri daha pozitif bir hal aldıkça bu dönemi kabullenip getirileriyle kolay baş edebilmek için aile hekimine başvurma sayısının arttığı ifade edilebilir.

Tablo 10. Yaşlılık Algısının Özel Hekim Hizmeti Kullanımına Etkisi

\begin{tabular}{|c|c|c|c|c|c|c|c|c|}
\hline \multicolumn{2}{|c|}{ Model } & \multicolumn{2}{|c|}{$\mathbf{R}$} & \multicolumn{3}{|l|}{$\mathbf{R}^{2}$} & $\begin{array}{c}\text { Düzeltilmiş } \\
\mathbf{R}^{2}\end{array}$ & $\begin{array}{l}\text { Standart } \\
\text { Hatanın } \\
\text { Tahmini }\end{array}$ \\
\hline \multicolumn{2}{|c|}{$\mathrm{X}_{4}$} & \multicolumn{2}{|c|}{0.112} & \multicolumn{3}{|l|}{0.013} & 0.011 & 0.879 \\
\hline \multirow{2}{*}{\multicolumn{2}{|c|}{ Model }} & \multicolumn{2}{|c|}{$\begin{array}{c}\text { Standartlaştırılmamış } \\
\text { Katsayılar }\end{array}$} & \multirow{2}{*}{\begin{tabular}{|c|}
$\begin{array}{c}\text { Standartlaştırılmış } \\
\text { Katsayılar }\end{array}$ \\
Beta \\
\end{tabular}} & \multirow{2}{*}{ F } & \multirow{2}{*}{$\mathrm{p}$} & \multirow{2}{*}{$\mathbf{t}$} & \multirow[b]{2}{*}{$\mathbf{p}$} \\
\hline & & B & $\begin{array}{l}\text { Standart } \\
\text { Hata }\end{array}$ & & & & & \\
\hline \multirow[t]{5}{*}{1} & Sabit & 0.788 & 0.256 & & \multirow{5}{*}{1.853} & \multirow{5}{*}{0.117} & 3.082 & 0.002 \\
\hline & $X_{1}$ & -0.003 & 0.053 & -0.002 & & & -0.051 & 0.959 \\
\hline & $X_{2}$ & -0.021 & 0.042 & -0.024 & & & -0.498 & 0.619 \\
\hline & $X_{3}$ & 0.056 & 0.054 & 0.051 & & & 1.034 & 0.302 \\
\hline & $X_{4}$ & -0.108 & 0.043 & -1.133 & & & -2.521 & 0.012 \\
\hline \multirow[t]{4}{*}{2} & Sabit & 0.782 & 0.225 & & \multirow{4}{*}{2.475} & \multirow{4}{*}{0.061} & 3.474 & 0.001 \\
\hline & $X_{2}$ & -0.021 & 0.042 & -0.025 & & & -0.504 & 0.615 \\
\hline & $X_{3}$ & 0.056 & 0.054 & 0.050 & & & 1.034 & 0.301 \\
\hline & $X_{4}$ & -0.108 & 0.043 & -0.113 & & & -2.530 & 0.012 \\
\hline & Sabit & 0.755 & 0.219 & & \multirow{3}{*}{3.591} & \multirow{3}{*}{0.028} & 3.456 & 0.001 \\
\hline & $X_{3}$ & 0.045 & 0.049 & 0.041 & & & 0.909 & 0.364 \\
\hline & $X_{4}$ & -0.110 & 0.043 & -0.112 & & & -2.577 & 0.010 \\
\hline & Sabit & 0.867 & 0.181 & & & & 4.795 & 0.000 \\
\hline & $X_{4}$ & -0.107 & 0.043 & -0.112 & 6.358 & 0.012 & -2.521 & 0.012 \\
\hline
\end{tabular}

Tablo 10'a göre özel hekim sağlık hizmeti kullanımındaki değişimin \%1.3'ünün $\left(R^{2}=0.013\right)$ bağımsız değişkenlerden "tecrübe ve örnek olma" tarafından açıklandığı ve modelin açıklayıcı gücünün anlamlılığı bakımından bir problem olmadığ1 görülmüştür ( $F=6.358, p=0.012)$. Bu açıdan "tecrübe ve örnek olma" boyutunun özel hekim sağlık hizmeti kullanımı üzerinde 
negatif yönlü bir etkisinin olduğu ve bu etkinin istatistiksel olarak anlamlı olduğu tespit edilmiştir. Öyle ki buradan şu sonuca varılmaktadır; yaşlılığı kabullenen ve tecrübe olunması gerektiğini düşünen bireyler özel hekime daha az sıklıkla başvurmakta ve daha az sağlık hizmeti talebi oluşturmaktadır.

Tablo 11. Yaşlılık Algısının Diş Hekimliği Hizmeti Kullanımına Etkisi

\begin{tabular}{|c|c|c|c|c|c|c|c|}
\hline Model & \multicolumn{2}{|c|}{$\mathbf{R}$} & \multicolumn{3}{|l|}{$\mathbf{R}^{2}$} & $\begin{array}{c}\text { Düzeltilmiş } \\
\mathbf{R}^{2}\end{array}$ & $\begin{array}{l}\text { Standart } \\
\text { Hatanın } \\
\text { Tahmini }\end{array}$ \\
\hline & \multicolumn{2}{|c|}{0.000} & \multicolumn{3}{|l|}{0.000} & 0.000 & 1.324 \\
\hline \multirow[t]{2}{*}{ Model } & \multicolumn{2}{|c|}{$\begin{array}{c}\text { Standartlaştırılmamış } \\
\text { Katsayılar }\end{array}$} & \multirow{2}{*}{\begin{tabular}{|c|}
$\begin{array}{c}\text { Standartlaştırılmıs } \\
\text { Katsayılar }\end{array}$ \\
Beta \\
\end{tabular}} & \multirow{2}{*}{ F } & \multirow{2}{*}{$\mathbf{p}$} & \multirow{2}{*}{$\mathbf{t}$} & \multirow{2}{*}{$p$} \\
\hline & B & $\begin{array}{l}\text { Standart } \\
\text { Hata }\end{array}$ & & & & & \\
\hline \multirow[t]{4}{*}{1} & 0.671 & 0.385 & & \multirow{5}{*}{0.410} & \multirow{5}{*}{0.802} & 1.741 & 0.082 \\
\hline & -0.016 & 0.079 & -0.009 & & & -0.203 & 0.839 \\
\hline & -0.070 & 0.063 & -0.055 & & & -1.112 & 0.267 \\
\hline & 0.072 & 0.081 & 0.044 & & & 0.887 & 0.375 \\
\hline$X_{4}$ & 0.026 & 0.065 & 0.018 & & & 0.401 & 0.689 \\
\hline $2 \quad$ Sabit & 0.634 & 0.339 & & \multirow{4}{*}{0.534} & \multirow{4}{*}{0.659} & 1.869 & 0.062 \\
\hline$X_{2}$ & -0.071 & 0.063 & -0.056 & & & -1.130 & 0.259 \\
\hline$X_{3}$ & 0.071 & 0.081 & 0.043 & & & 0.874 & 0.383 \\
\hline$X_{4}$ & 0.025 & 0.064 & 0.018 & & & 0.392 & 0.695 \\
\hline \multirow[t]{2}{*}{3} & 0.730 & 0.233 & & \multirow{3}{*}{0.725} & \multirow{3}{*}{0.485} & 3.128 & 0.002 \\
\hline & -0.069 & 0.063 & -0.054 & & & -1.104 & 0.270 \\
\hline$X_{3}$ & -0.047 & 0.081 & 0.043 & & & 0.888 & 0.375 \\
\hline \multirow[t]{2}{*}{$4 \quad$ Sabit } & 0.859 & 0.183 & & & & 4.694 & 0.000 \\
\hline & -0.047 & 0.057 & -0.036 & 0.663 & 0.416 & -0.814 & 0.416 \\
\hline
\end{tabular}

Tablo 11' de modelin açıklayıcı gücünün anlamlılığı bakımından yeterli olmadığı görülmüştür ( $\mathrm{F}=0.663, \mathrm{p}=0.416)$. Bu açıdan yaşlılık algısı boyutlarının diş hekimliği sağlık hizmeti kullanımı üzerinde bir etkisinin olmadığı tespit edilmiştir. Buradan diş hekimi sağlık hizmeti kullanımının bireylerin yaşlılık algısından etkilenmediği sonucuna ulaşılabilir.

Tablo 12. Yaşlılık Algısının Klinik Hizmeti Kullanımına Etkisi

\begin{tabular}{|c|c|c|c|c|c|c|c|}
\hline Model & \multicolumn{2}{|c|}{$\mathbf{R}$} & \multicolumn{3}{|l|}{$\mathbf{R}^{2}$} & $\begin{array}{l}\text { Düzeltilmiş } \\
\qquad \mathbf{R}^{2}\end{array}$ & $\begin{array}{l}\text { Standart } \\
\text { Hatanın } \\
\text { Tahmini }\end{array}$ \\
\hline$X_{1}$ & \multicolumn{2}{|c|}{0.088} & \multicolumn{3}{|l|}{0.008} & 0.006 & 0.408 \\
\hline \multirow[t]{2}{*}{ Model } & \multicolumn{2}{|c|}{$\begin{array}{c}\text { Standartlaştırılmamış } \\
\text { Katsayılar }\end{array}$} & $\begin{array}{c}\text { Standartlaştırılmış } \\
\text { Katsayılar }\end{array}$ & \multirow{2}{*}{$\mathbf{F}$} & \multirow{2}{*}{ p } & \multirow{2}{*}{$\mathbf{t}$} & \multirow{2}{*}{$\mathrm{p}$} \\
\hline & B & $\begin{array}{c}\text { Standart } \\
\text { Hata }\end{array}$ & Beta & & & & \\
\hline
\end{tabular}


Tablo 12. Yaşlılık Algısının Klinik Hizmeti Kullanımına Etkisi (Devamı)

\begin{tabular}{|cc|c|c|c|c|c|c|c|}
\hline 1 & Sabit & -0.068 & 0.119 & & & & -0.568 & 0.570 \\
& & & & & & & \\
& $\mathrm{X}_{1}$ & 0.044 & 0.024 & 0.082 & 1.333 & 0.257 & 1.804 & 0.072 \\
& $\mathrm{X}_{2}$ & 0.001 & 0.019 & 0.003 & & & 0.055 & 0.956 \\
& $\mathrm{X}_{3}$ & 0.027 & 0.025 & 0.053 & & & 1.070 & 0.285 \\
& $\mathrm{X}_{4}$ & -0.002 & 0.020 & -0.005 & & & -0.103 & 0.918 \\
\hline 2 & Sabit & -0.066 & 0.117 & & & & -0.568 & 0.570 \\
& & & & & & & & \\
& $\mathrm{X}_{1}$ & 0.044 & 0.024 & 0.082 & 1.780 & 0.150 & 1.814 & 0.070 \\
& $\mathrm{X}_{3}$ & 0.027 & 0.023 & 0.054 & & & 1.188 & 0.235 \\
& $\mathrm{X}_{4}$ & -0.002 & 0.020 & -0.004 & & & -0.099 & 0.921 \\
\hline 3 & Sabit & -0.074 & 0.090 & & & & -0.821 & 0.412 \\
& & & & & & & & \\
& $\mathrm{X}_{2}$ & 0.044 & 0.024 & 0.082 & 2.670 & 0.070 & 1.813 & 0.070 \\
& $\mathrm{X}_{3}$ & 0.027 & 0.023 & 0.053 & & & 1.186 & 0.236 \\
\hline 4 & Sabit & -0.010 & 0.072 & & & & -0.137 & 0.891 \\
& & & & & & & & \\
& $\mathrm{X}_{1}$ & 0.048 & 0.024 & 0.088 & 3.931 & 0.048 & 1.983 & 0.048 \\
\hline
\end{tabular}

Tablo 12'ye göre klinik hizmeti kullanımındaki değişimin \%0.8'inin $\left(\mathrm{R}^{2}=0.008\right)$ bağımsız değişkenlerden "olumlu beklentiler" tarafından açıklandığı ve modelin açıklayıcı gücünün anlamlılığı bakımından bir problem olmadığı görülmüştür ( $\mathrm{F}=3.931, \mathrm{p}=0.048)$. Bu bakımdan "psikososyal kayıp" boyutunun klinik hizmeti kullanımı üzerinde pozitif yönlü bir etkisinin olduğu ve bu etkinin istatistiksel olarak anlamlı olduğu sonucuna varılmıştır. Öyle ki bireyler yaşlılıkta kendilerinde meydana gelecek kayıpları önlemek adına daha fazla sağlık hizmeti kullanıp kliniğe başvurmaktadır.

Tablo 13. Yaşlılık Algısının Eczane Hizmeti Kullanımına Etkisi

\begin{tabular}{|c|c|c|c|c|c|c|c|c|}
\hline \multicolumn{2}{|c|}{ Model } & \multicolumn{2}{|c|}{$\mathbf{R}$} & \multicolumn{3}{|l|}{$\mathbf{R}^{2}$} & $\begin{array}{c}\text { Düzeltilmiş } \\
\mathbf{R}^{2}\end{array}$ & $\begin{array}{l}\text { Standart } \\
\text { Hatanın } \\
\text { Tahmini }\end{array}$ \\
\hline & $\begin{array}{l}X_{3} \\
X_{4}\end{array}$ & \multicolumn{2}{|c|}{0.115} & \multicolumn{3}{|c|}{0.013} & 0.009 & 3.884 \\
\hline \multirow{2}{*}{\multicolumn{2}{|c|}{ Model }} & \multicolumn{2}{|c|}{$\begin{array}{c}\text { Standartlaştırılmamış } \\
\text { Katsayılar }\end{array}$} & $\begin{array}{c}\text { Standartlaştırılmış } \\
\text { Katsayılar }\end{array}$ & \multirow{2}{*}{ F } & \multirow{2}{*}{ p } & \multirow{2}{*}{$t$} & \multirow{2}{*}{ p } \\
\hline & & B & $\begin{array}{l}\text { Standart } \\
\text { Hata }\end{array}$ & Beta & & & & \\
\hline & Sabit & 2.162 & 1.128 & & \multirow{5}{*}{2.246} & \multirow{5}{*}{0.063} & 1.917 & 0.056 \\
\hline & $X_{1}$ & 0.249 & 0.232 & 0.048 & & & 1.073 & 0.284 \\
\hline & $X_{2}$ & 0.183 & 0.185 & 0.049 & & & 0.994 & 0.321 \\
\hline & $X_{3}$ & 0.317 & 0.238 & 0.065 & & & 1.333 & 0.183 \\
\hline & $X_{4}$ & -0.351 & 0.189 & -0.083 & & & -1.857 & 0.064 \\
\hline & Sabit & 2.358 & 1.110 & & \multirow{4}{*}{2.665} & \multirow{4}{*}{0.047} & 2.124 & 0.034 \\
\hline & $\mathrm{X}_{1}$ & 0.265 & 0.232 & 0.052 & & & 1.145 & 0.253 \\
\hline & $x_{3}$ & 0.410 & 0.219 & 0.084 & & & 1.875 & 0.061 \\
\hline & $X_{4}$ & -0.337 & 0.188 & -0.080 & & & -1.790 & 0.074 \\
\hline
\end{tabular}


Tablo 13. Yaşlılık Algısının Eczane Hizmeti Kullanımına Etkisi (Devamı)

\begin{tabular}{|cc|c|c|c|c|c|c|c|}
\hline 3 & Sabit & 2.987 & 0.965 & & & & 3.094 & 0.002 \\
& & & & & & & \\
& $\mathrm{X}_{3}$ & 0.442 & 0.217 & 0.091 & 3.340 & 0.036 & 2.035 & 0.042 \\
$\mathrm{X}_{4}$ & -0.325 & 0.188 & -0.077 & & & -1.729 & 0.084 \\
\hline
\end{tabular}

Tablo 13'e göre eczane hizmeti kullanımındaki değişimin \%1.3'ünün $\left(\mathrm{R}^{2}=0.013\right)$ bağımsız değişkenlerden "olumlu beklentiler" ve "tecrübe ve örnek olma" tarafından açıklandığı tespit edilmiştir. Bunun yanı sıra modelin açıklayıcı gücü anlamlılığı bakımından yeterli bulunmuştur ( $\mathrm{F}=3.340, \mathrm{p}=0.036)$. "Olumlu beklentiler" boyutunun eczane hizmeti kullanımı üzerinde pozitif yönlü bir etkisinin olduğu ve bu etkinin istatistiksel olarak anlamı olduğu görülmüştür. Bunun yanı sıra "tecrübe ve örnek olma" boyutunun eczane hizmeti kullanımı üzerinde negatif yönlü bir etkisinin olduğu ancak bu etkinin istatistiksel olarak anlamı olmadığı sonucunda varılmıştır. Bu açıdan bireylerin, yaşlılığa dair beklentileri olumlu hale geldikçe eczane hizmetinden daha fazla yararlandıkları görülmektedir. Diğer yandan bireylerin yaşlılığı gençlere tecrübe ve örnek olunması gereken bir dönem olarak algılamalarının eczane hizmeti kullanımına bir etkisinin olmadığı tespit edilmiştir.

\section{Sonuç ve Öneriler}

Modern zaman, toplumların bazı özelliklerini değiştirmesi ve dönüştürmesi nedeniyle literatürde sıklıkla ele alınan bir konu olmuştur. Yaşlılık algısı da bu anlamda eskiye nazaran bazı dönüşümler yaşamış ve insanlar artık yaşlılığı bir yük olarak gördüğü için önceleri yaşından dolayı tecrübeli görülen, saygı duyulan insanlar artık toplumdan dışlanmakta ve kendilerine yer bulamamaktadır. Şahin (2015: 123)'e göre yaşlılık artık bireysel bir sorun olmaktan çıkmış ve toplumların üzerinde durduğu bir konu haline gelmiştir. Yaşlıların karşı karşıya kaldıkları sorunların temelinde fiziksel, ruhsal, ekonomik ve çevresel faktörler yer almaktadır. Ayrıca yaşlının yaşadığı ülkenin sosyal, ekonomik ve kültürel politikaları da bu konuda önem arz etmektedir.

$\mathrm{Bu}$ çalışmada sağlık hizmeti kullanımı sorularına verilen cevaplardan yola çıkıldığında katılımcıların poliklinik ve eczane hizmeti kullanım sayısının diğer hizmet türlerine göre daha yüksek olduğu tespit edilmiştir. Ayrıca aile hekimliğinin poliklinik hizmetine nazaran daha az kullanılması Türkiye'deki birinci basamak hizmetlerinden olan aile hekimliğinin uygulanabilirliği açısından ipucu vermektedir.

Elde edilen sonuçlara göre yaşlılık algısı boyutlarından "tecrübe ve örnek olma" ve "pozitif değerlendirme" yüksek; "psikososyal kayıp" ve "olumlu beklentiler" faktörleri düşük puan almıştır. Modern zamanda yaşlılık algısında yaşanan dönüşümün sağlık hizmetlerine etkisinin araştırıldığı bu çalışmada yaşlılık algısı boyutlarından "tecrübe ve örnek olma"ya en yüksek katılımın sağlaması yaşlılığın da kabul edildiğini göstermektedir. $\mathrm{Bu}$ açıdan katılımcılar, modern zamandaki yaşlılık algısına sahip olmayıp yaşlılığ başkasına muhtaç olunan ve kendi kendine yetmenin mümkün olmadığı düşkünlük dönemi şeklinde görmemektedir. Öte yandan katılımcılar yaşlılığı kayıpların olduğu bir dönem şeklinde algılamamakta ve bu döneme karşı olumlu beklentiler beslemedikleridir. Yıldız (2018: 83)'ın lise öğrencilerinin yaşlılık algısını ölçüldüğü çalışmasında katılımcılar ilerde huzurevinde kalmak istemediklerini ifade etmiş ve bir noktada yaşlılı̆̆ın kurumsallaşan yapısını benimsememiştir. 
Çalışmanın merak edilen hususlarından biri yaşlılık algısının sağlık hizmeti kullanımına etkisidir. Bireyler yaşlılığı; kayıpların olduğu bir dönem şeklindeki algıladıkça daha fazla poliklinik, aile hekimi ve klinik hizmeti kullandığı tespit edilmiştir. Yani bu dönemde belli yeti kayıplarına uğrayacağına inanan bireyler daha fazla bu hizmetleri kullanmıştır. Ayrıca bireyler yaşlılı̆̆a dair; pozitif değerlendirmeler yaptıkça daha fazla aile hekimi, olumlu beklentiler içinde oldukça daha fazla eczane hizmeti kullanmaktadır. Bu dönemi gençlere örnek olunacak bir zaman dilimi olarak görmek demek aynı zamanda tecrübe aktarımının bu zamanda olacağına dair bir algıyı içinde barındırmaktadır ki bu algının yüksek olduğu insanlar özel hekime daha az başvurmuştur.

Yapılan çalışmadan geliştirilecek öneri ise şu şekildedir; Yaşlılık bakım hizmetleri ve yaşlılık algısı arasındaki etkiyi ortaya koyabilmek için yaşlı bakım merkezlerine belirli bir yıldan başlayarak başvuran kişi sayısı üzerinden bir araştırma yapılabilir. Bu sayede dönüşen yaşlılık algısının kurumsallaşması hakkında daha detaylı bilgi elde edinilmiş olunacaktır.

\section{Teşekkür ve Bilgilendirme}

Bu çalışma Rabia Fettahoğlu'nun “Bireylerin Yaşlılık ve Ölüm Algısının Sağlık Hizmeti Kullanımına Etkisi" adlı yüksek lisans tezinden türetilmiştir. Bu çalışma 20-23 Haziran 2019 tarihinde İstanbul'da düzenlenen 4. Uluslararası Sağlık Bilimleri ve Yönetim Kongresi'nde bildiri olarak sunulmuştur. Bu çalışma Süleyman Demirel Üniversitesi Bilimsel Araştırma Projeler Koordinasyon Birimince Prof. Dr. Ramazan ERDEM tarafından yürütülen SYL-20186902 numaralı ve "Bireylerin Yaşlılık ve Ölüm Algısının Sağlık Hizmeti Kullanımına Etkisi" başlıklı Yüksek Lisans Tez Projesi kapsamında desteklenmiştir. 


\section{Kaynakça}

Aile ve Sosyal Politikalar Bakanlığı, (2012). Türkiye' de yaşlıların durumu ve yaşlanma ulusal eylem planı uygulama programı. Ankara.

Akın, G. (2002). Başlangıçtan günümüze yaşlının aile ve toplumdaki statüsü, Geriatri, 5(1), 75.

Aksu, G., Eser, M. T. \& Güzeller, C. O. (2017). Açımlayıcı ve Doğrulayıcı Faktör Analizi ile Yapısal Eşitlik Modeli Uygulamaları. 1. Baskı, Ankara: Detay Yayıncılık.

Akülkü, H. (2015). Yaşlıların yaşlllık algısı: Antalya/Finike ve Polonya/Rzeszow örneği (Yüksek Lisans Tezi, Abant İzzet Baysal Üniversitesi, Bolu).

Blagosklonny, M. V. \& Salon, M. N. (2009). Growth and aging: A common molecular mechanism, Aging, 1(4), 357-362.

Bulduk, E. Ö. (2014). Yaşlılık ve toplumsal değişim, Türkiye Sosyal Araştırmalar Dergisi, 2, 5360.

Efe, E., Bek, Y. \& Şahin, M. (2000). SPSS'de çözümleri ile istatistik yöntemler II, Kahramanmaraş: Kahramanmaraş Sütçü İmam Üniversitesi Rektörlüğü.

Erdem, R. \& Pirinçci, E. (2003). Sağlık hizmetlerinde kullanım ve kullanımı etkileyen faktörler, Ondokuz Mayıs Üniversitesi Tıp Dergisi, 20(1), 39-46.

Ertaş, H. \& Kıraç, F. Ç. (2019). Hastaların sağlık hizmeti kullanım durumlarının incelenmesi, 2. Uluslararası Sosyal ve Eğitim Bilimleri Sempozyumu, Konya.

Ertaylan, A. (2016). 1990 sonrası Türkiye sinemasında yaşlılık temsilleri, The Turkish Online Journal of Design, 6(1), 1-20.

Eser, E., Gerçeklioğlu, G., Eser, S,, Fidaner, C., Baysan, P., Pala, T. vd. (2011). Dünya sağlık örgütü avrupa yaşlanma tutumu anketi (aaq)" türkçe sürümünün (ayta-tr) psikometrik özellikleri, Turkish Journal of Geriatrics, 14:101-110.

Gökkaya, D. \& Erdem, R., (2017), “Sağlık hizmetleri kullanımına etki eden faktörlerin hastalık şiddeti algısıyla değerlendirilmesi", Süleyman Demirel Üniversitesi Sosyal Bilimler Enstitüsü Dergisi, 1(26): 149-184.

Harman, D. (1981). The aging process, Medical Sciences, Proceedings of the National Academy of Sciences of the USA, 78(11), 7124-7128.

Hooyman, N. R., Kawamoto, K. Y. \& Kiyak, H. A. (2015). Aging Matters an Introduction to Social Gerontology, Boston: Pearson Education.

İlhan, M. N., Tüzün, H., Aycan, S., Aksakal, F. N. \& Özkan, S. (2006). Birinci basamak sağlık kuruluşuna başvuranların sağlık hizmeti kullanma özellikleri ve bazı sosyoekonomik belirteçlerle değişimi: Sağlık reformu öncesi son saptamalar, Toplum Hekimliği Bülteni, 25(3), 33-41.

Kaya, S. (1995). Sağlık bakım hizmetlerinin kullanılabilirliği, Toplum ve Hekim, 10(66), 101-106.

Koca, H., (1994), Ülkemiz koşullarında yaşlılık ve yaşlının sosyal uyumunun araştırılması (alan araştırması) (Yüksek Lisans Tezi, İstanbul Üniversitesi, İstanbul).

Konak, A. \& Çiğdem, Y., (2005), Yaşlılık olgusu: Sivas huzurevi örneği, Cumhuriyet Üniversitesi Sosyal Bilimler Dergisi, 29 (1), 23-63.

Kuné, J. B. (2003). On global aging old-age income systems in the eu and other major parts of the world, Contributions to Economics, New York: Physica-Verlag.

Kurt, G. (2008). Türkiye'de yaşllılık olgusuna sosyolojik bir bakış (sivas il örneği) (Yüksek Lisans Tezi, Cumhuriyet Üniversitesi, Sivas).

Kurtkapan, H. (2017). Kentleşme sürecinde yaşlılık ve yerel yönetim uygulamaları: İstanbul örneği (Doktora Tezi, İstanbul Üniversitesi, İstanbul). 
Kutsal, Y. G., (2003), "Yaşlanan dünya, yaşlanan toplum, yaşlanan insan”, Hacettepe Toplum Hekimliği Bülteni, 3(4): 1-5.

National Research Council, (2001), Preparing for an aging world, The Case for Cross-National Research, Washington: National Academy Press.

Özdamar, K. (2017). Eğitim, sağlık ve davranış bilimlerinde ölçek ve test geliştirme yapısal eşitlik modellemesi, Eskişehir: Nisan Yayınları.

Özenci, C. (2017). Yönetim, liderlik ve değişim bağlamında, gençlik merkezi yöneticilerinin inovasyon yeterliklerinin ölçülmesi; bir alan araştırması (Yüksek Lisans Tezi, Hitit Üniversitesi, Çorum).

Parlak, E. A., Erdem, R., Alsaifi, D. I. J. \& Aborass, N. (2015). Aging and aging policies in Turkey, içinde F. Akıncı, S. Bostan Ve T. Kılıç (Ed.), International Healtcare Management Conference, (ss. 579- 582), Ankara: Gümüşhane Üniversitesi Yayınları.

Silverstein, M., Burholt, V., Wenger, G. C. \& Bengston, V. L. (1998). Parent-child relations among very old parents in wales and the united states: a test of modernization theory, Journal of Aging Studies, 2(4), 387- 409.

Siyasi Partiler Kanunu (Kabul tarihi: 22.4.1983, Karar sayıs1: 18027, Resmi Gazete: 24.4.1983).

Şahin, H. (2015). Yaşlılık Algısı ve Yaşlılara Sunulan Kurumsal Hizmetler Farkındalığı Üzerine Bir İnceleme: Erzurum İli Örneğinde (Yüksek Lisans Tezi, Atatürk Üniversitesi, Erzurum).

Taşkesen, C. G. (2017). Kırsal ve kentsel alanlarda yaşlanma, yaşlılık ve yaşlılar: Denizli ili örneği, Mehmet Akif Ersoy Üniversitesi İktisadi ve İdari Bilimler Fakültesi Dergisi, 4(1): 92-124.

TDK Güncel Türkçe Sözlük,

http://www.tdk.gov.tr/index.php?option=com gts\&arama=gts\&guid=TDK.GTS.5c430adbce2 $\underline{\mathrm{f} 21.02840452}$ (19.01.2019).

Tufan, İ. (2016). Antik çă̆dan günümüze yaşlılık ve yaşlanma, II. Basım, Ankara: Nobel Yayınları. TUIK, (2018). İl Nüfusu, https://biruni.tuik.gov.tr/medas/?kn=95\&locale=tr (Erişim: 03.07.2019).

Tümerdem, Y. (2006). Gerçek yaş, Turkish Journal of Geriatrics, 9(3), 195-196.

Türk Medeni Kanunu (Kabul tarihi: 22.11.2001, Karar sayısı: 24607, Resmi Gazete: 8.12.2001)

Victor, C. R., (1994), Old age in modern society: A textbook of social gerontology, London: Chapman \& Hall.

Yazıcıoğlu, Y. \& Erdoğan, S. (2004). SPSS uygulamalı bilimsel araştırma yöntemleri, Ankara: Detay Yayıncilik.

Yıldız, M. (2018). Lise öğrencilerinde yaşlı ve huzurevi algısı: İstanbul örneği, İstanbul Sabahattin Zaim Üniversitesi Sosyal Bilimler Enstitüsü Sosyal Hizmet Anabilim Dalı Sosyal Hizmet Bilim Dalı, İstanbul. 